\title{
Selenium concentrations in coho salmon outmigrant smolts and returning adults: a comparison of wild versus hatchery-reared fish $^{*}$
}

\author{
Samuel P. Felton, Wenjuan Ji**, Stephen B. Mathews \\ Fisheries Research Institute, University of Washington, Seattle, Washington 98195, USA
}

\begin{abstract}
Selenium levels were compared in wild and hatchery-reared coho salmon Oncorhynchus kisutch. Selenium concentrations were measured in the liver of returning adult fish and in whole body samples of outmigrant smolts. In each case, selenium levels in wild coho salmon were approximately twice as high as those in hatchery-reared fish. These comparisons will offer some guidelines to investigators conducting studies relating selenium concentrations with disease potentials and/or resistances in fishes. The significance of differences in the concentrations of selenium and other micronutrients found in cultured and wild fish is discussed.
\end{abstract}

There is considerable interest among aquaculturists and hatchery managers in what constitutes an adequate selenium concentration for good health in fish, particularly in salmonids (Ringdal \& Julshamn 1985). The primary purpose of this paper is to report differences in selenium concentrations between wild and hatchery-cultured coho salmon Oncorhynchus kisutch. Although fish are known to incorporate selenium from waterborne sources (Hodson \& Hilton 1983) as well as from inorganic and organic dietary sources (Bell \& Cowey 1989), the sources of the selenium found in fish tissues in this study were beyond the scope of the study. However, fish culturists may obtain some dietary guidelines from our data.

Post-release survival rates of hatchery-reared Pacific salmon Oncorhynchus spp. have steadily improved in recent decades; however, generally speaking, naturally reared salmon survive the time between outmigration and adulthood at higher rates than hatchery-

\footnotetext{
- Contribution no. 816, School of Fisheries, University of Washington

- Visiting scientist from Yellow Sea Fisheries Research Institute, Quingdao, China
}

reared salmon. There are, of course, many factors that might contribute to these observed differences in postrelease survival rates, including differences in nutrition. This paper describes work in our laboratory, and in the laboratories of other investigators, to measure the concentration of selenium in natural and hatcheryreared coho salmon. Selenium is apparently an important micronutrient in the disease immunity system.

\section{METHODS}

Tissue collection from adult coho salmon. Whole livers from adult salmon were obtained from the following sources: (1) 10 fish caught at the entrance to the Strait of San Juan de Fuca were donated by Makah Indian Seafood Co., Sekiu, Washington; (2) 10 fish caught in Puget Sound or its estuaries were furnished by Commercial Sea Food Products of Puget Sound, Mukilteo, Washington; (3) 10 fish returning to a hatchery were donated by the University of Washington School of Fisheries; and (4) 10 fish raised in saltwater net pens were donated by Domsea Farms, Manchester, Washington. The average body weight and sampling dates for these fish were as follows: ocean-caught fish $=3.20 \mathrm{~kg}$, sampled on October 26, 1987; Puget Sound and estuarine coho $=2.50 \mathrm{~kg}$, sampled October 27 , 1987; University of Washington hatchery return fish $=$ $1.21 \mathrm{~kg}$, sampled September 30, 1987; and the net-pen fish $=1.66 \mathrm{~kg}$, sampled December 30, 1987. The livers were individually wrapped and bagged in plastic, then kept frozen at $-20^{\circ} \mathrm{C}$ until each was digested for selenium analysis.

Tissue collection from outmigrant smolts. Smolts from 2 populations of late spawning Satsop River 
Table 1 Oncorhynchus kisutch. Selenium concentrations (mean and standard deviation) in the livers of adult coho salmon foraging in the ocean and of adult coho salmon raised entirely in captivity. Statistical significance of difference in selenium concentration $\mathrm{p}<0.05$ (values with different letter superscripts are significantly different)

\begin{tabular}{|c|c|c|c|c|}
\hline Sample origin & $N$ & Total liver wt $(\mathrm{g})$ & $\begin{array}{c}{[\text { Se] }} \\
\left(\mu \mathrm{g} \mathrm{g}{ }^{-1} \mathrm{dry} w t\right)\end{array}$ & $\begin{array}{c}{[\mathrm{Se}]} \\
\left(\mu \mathrm{g} \mathrm{g}^{-3} \text { wet } w \mathrm{t}\right)\end{array}$ \\
\hline Ocean caught & 10 & $\begin{array}{r}\bar{X} 76.79 \\
S D 18.98\end{array}$ & $\begin{array}{l}8.76 \\
1.90\end{array}$ & $\begin{array}{l}1.71^{\mathrm{a}} \\
0.40^{\circ}\end{array}$ \\
\hline Estuary caught & 10 & $\begin{array}{r}\bar{X} 59.44 \\
\text { SD } 14.57\end{array}$ & $\begin{array}{l}8.12 \\
2.39\end{array}$ & $\begin{array}{l}1.64^{\mathrm{d}} \\
0.47\end{array}$ \\
\hline Hatchery return & 10 & $\begin{array}{r}\bar{X} 28.80 \\
\mathrm{SD} 19.11\end{array}$ & $\begin{array}{l}7.56 \\
2.86\end{array}$ & $\begin{array}{l}1.58^{d} \\
0.60\end{array}$ \\
\hline Farmed fish & 10 & $\begin{array}{r}\bar{X} 39.93 \\
\text { SD } 10.50\end{array}$ & $\begin{array}{l}4.82 \\
2.50\end{array}$ & $\begin{array}{l}1.00^{\mathrm{b}} \\
0.50\end{array}$ \\
\hline
\end{tabular}

(Grays Harbor County, Washington) coho were obtained from the Washington Department of Fisheries (WDF) through a hatchery located on Bingham Creek (a tributary of the Satsop River). As returning adult salmon migrate upstream, a portion of the fish are trapped and used to supply eggs for the Bingham Creek Hatchery. The remaining fish are allowed to pass above the weir to spawn naturally. Progeny remain in the hatchery or in the creek for approximately $15 \mathrm{mo}$. When the process of smoltification is complete, the juvenile fish begin a downstream migration to their saltwater feeding grounds.

On May 18, 1988, naturally reared smolts ( $\mathrm{n}=20$ ) with an average weight of $14.28 \mathrm{~g}$ were netted from the outmigration trap on Bingham Creek, and hatcheryreared smolts ( $\mathrm{n}=20$ ) with an average weight of $22.70 \mathrm{~g}$ were netted from a rearing pond. The hatcheryreared fish had been fed a pelleted diet (Oregon Moist Pellet, Moore-Clark Co., LaConner, Washington) that contained 0.7 to $0.9 \mathrm{mg}$ selenium $\mathrm{kg}^{-1}$ (Felton et al. 1989). Selenium levels in the diet of naturally reared fish are unknown.

Whole body samples were wrapped and bagged in plastic and held on ice for several hours, then frozen at $-20^{\circ} \mathrm{C}$ until they were digested for selenium analysis.

Selenium analysis. Liver tissue from each adult fish or tissues from individual whole smolts were homogenized in a Waring blender at top speed for $1.5 \mathrm{~min}$. Aliquots ( 1.0 to $2.0 \mathrm{~g}$ wet wt for liver tissue; 0.8 to $1.0 \mathrm{~g}$ wet wt for whole body carcass tissue) were digested using a method described by Adeloju \& Bond (1983). The resulting digested material was analyzed directly or, if the background was too high, it was analyzed using the following modification: $1 \mathrm{ml}$ of the digest was adjusted to $\mathrm{pH} 6.5$ to 7.0 using $10 \mathrm{~N}$ sodium hydroxide with cooling. The pH-adjusted aliquot was then passed through a water-washed chelex column with a bed size of $1 \times 4 \mathrm{~cm}$ (Bio Rad Products, Richmond, CA). The column was washed with enough water to achieve a volume of $8 \mathrm{ml}$. The volume was then brought to $10 \mathrm{ml}$ with the addition of $1 \mathrm{ml}$ of $2 \mathrm{~N}$ $\mathrm{HCl}$ and $1 \mathrm{ml}$ of $5 \mathrm{ppm} \mathrm{Cu}{ }^{++}$as copper sulfate.

Samples were assayed for total selenium by the direct method of cathodic stripping voltometry at a dropping mercury electrode (Princeton Applied Research Polarograph, Model 374, Princeton, NJ). Polarograph settings were as follows: initial potential $0.35 \mathrm{~V}$ vs $\mathrm{Ag} / \mathrm{AgCl}$, final potential $0.750 \mathrm{~V}$ vs $\mathrm{Ag} / \mathrm{AgCl}$, no conditional potential, deposition time $180 \mathrm{~s}$, scan rate-fast, replications-one, and a sensitivity setting of medium.

Calculations were made by the method of standard addition with sodium selenite (Sigma Chemical Co., St. Louis, MO). Spiked samples were analyzed with a recovery of 90 to $95 \%(\mathrm{n}=3)$. NBS (bovine liver) standard in our assay system $(n=3)$ gave a concentration of $1.25 \mathrm{\mu g} \mathrm{g}^{-1}$ (dry weight basis); the certified value was $1.1 \pm 0.1 \mathrm{\mu g} \mathrm{g}^{-1}$.

\section{RESULTS}

Selenium levels in the livers of wild adult fish were ca 1.64 times greater than noted in the livers of hatchery-reared adult fish (Table 1). Hepatic selenium levels were significantly different among the 4 groups $\left(\mathrm{F}_{3,36}=\right.$ 4.226, $\mathrm{p}<0.025$ ). The mean selenium level in the

Table 2. Oncorhynchus kisutch. Selenium concentrations (mean and standard deviation) in whole body samples of hatchery-reared and naturally reared coho salmon smolts Statistical significance of difference in selenium concentration. $\mathrm{p}<0.0025$

\begin{tabular}{|c|c|c|c|c|}
\hline $\begin{array}{l}\text { Sample } \\
\text { origin }\end{array}$ & $N$ & $\begin{array}{l}\text { Tissue wt } \\
\qquad(\mathrm{g})\end{array}$ & $\begin{array}{c}{[\mathrm{Se}]} \\
\left(\mu \mathrm{g} \mathrm{g} \mathrm{g}^{-1} \mathrm{dry} w \mathrm{wt}\right)(\mu \mathrm{gg} g\end{array}$ & $\begin{array}{l}{[\mathrm{Se}]} \\
\left.y^{-1} \text { wet } w t\right)\end{array}$ \\
\hline $\begin{array}{l}\text { Hatchery } \\
\text { reared }\end{array}$ & 20 & $\begin{array}{r}\bar{X} 0.88 \\
\text { SD } 0.05\end{array}$ & $\begin{array}{l}1.974 \\
1.160\end{array}$ & $\begin{array}{l}0.407 \\
0239\end{array}$ \\
\hline $\begin{array}{l}\text { Naturally } \\
\text { reared }\end{array}$ & 20 & $\begin{array}{r}\bar{X} 0.86 \\
\text { SD } 0.03\end{array}$ & $\begin{array}{l}3.630 \\
2.050\end{array}$ & $\begin{array}{l}0.749 \\
0.424\end{array}$ \\
\hline
\end{tabular}


Table 3. Oncorhynchus kisutch. Post-release survival rates $(\%)$ of hatchery- and naturally reared coho salmon, Puget Sound, $1977-78$ brood years. Data source: David Seiler, Washington Department of Fisheries, Olympia, Washington (pers. comm.)

\begin{tabular}{|c|c|c|c|}
\hline \multicolumn{2}{|c|}{ Hatchery smolts } & \multicolumn{2}{|c|}{ Wild smolts } \\
\hline Hatchery & Survival rate $(\%)$ & Stream & Survival rate $(\%)$ \\
\hline \multicolumn{4}{|l|}{1977 brood } \\
\hline Issaquah Creek & 10.76 & So. Fork Skykomish & 17.40 \\
\hline Soos Creek & 9.59 & Big Beef Creek & 29.20 \\
\hline Crisp Creek & 16.61 & Deschutes River & 21.10 \\
\hline Puyallup River & 13.53 & & \\
\hline Minter Creek & $14.01^{a}$ & & \\
\hline George Adams & $14.75^{b}$ & & \\
\hline \multicolumn{4}{|l|}{1978 brood } \\
\hline Issaquah Creek & 7.47 & So. Fork Skykomish & 15.30 \\
\hline Soos Creek & $8.94^{c}$ & Big Beef Creek & 17.40 \\
\hline Crisp Creek & 10.86 & Deschutes River & 20.70 \\
\hline Puyallup River & $10.15^{\mathrm{d}}$ & & \\
\hline Minter Creek & 14.67 & & \\
\hline George Adams & 15.53 & & \\
\hline \multicolumn{4}{|c|}{ Average of (a) 4 (b) 2 (c) 9 (d) 3 lots } \\
\hline
\end{tabular}

group of fish raised in saltwater net pens (Domsea Farms) was significantly lower than the mean selenium level in each of the 3 groups of fish that foraged naturally in saltwater (Student-Newman-Keuls test, $p<0.05$ ). Mean hepatic selenium levels in the 3 naturally foraging groups did not differ significantly from one another ( $p>0.05$ )

Whole body selenium concentrations in smolts averaged $0.407 \mathrm{mg} \mathrm{g}^{-1}$ wet wt for the hatchery-reared fish and $0.749 \mathrm{mg} \mathrm{g}^{-1}$ for the naturally reared fish (Table 2). The difference in means was statistically significant (Students' $t=3.14 ; \mathrm{df}=38 ; 1$-tailed $\mathrm{p}<0.0025$ ).

\section{DISCUSSION}

It has often been stated or implied, although not often demonstrated, that naturally spawned and reared salmonid smolts survive to adulthood at higher rates than hatchery smolts of similar genetic makeup which are released and outmigrate at ages, sizes and dates similar to their wild counterparts. Two replicated sets of unpublished observations from the Washington Department of Fisheries field work based upon coded wire tagging of smolts and recaptures of adults amply demonstrate higher survivability of wild smolts. Observations of Puget Sound coho salmon showed that survival rates were 1.5 to 2.0 times higher for wild fish than hatchery-reared fish (Table 3). Similar comparisons involving fall chinook salmon Ocorhynchus tshawytscha transiting the North Fork of the Lewis River (Columbia River tributary) showed higher survival of wild fish for each of 3 brood years (Table 4).

Greater resistance to disease is one of many possible
Table 4. Oncorhynchus tschawytscha. Post-release survival rates $(\%)$ of naturally and hatchery-reared fall chinook salmon smolts, North Fork Lewis River, $1977-79$ brood years. Data source: Donald McIsaac, Washington Department of Fisheries, Battleground, Washington (pers. comm.)

\begin{tabular}{|lccc|}
\hline & 1977 & 1978 & 1979 \\
\hline Naturally reared & 1.81 & 0.45 & 1.08 \\
Hatchery-reared & 0.37 & 0.32 & 0.57 \\
\hline
\end{tabular}

explanations for higher survivability of naturally produced salmonid smolts. Because fish health and disease are such important considerations in survivability within hatcheries, it is highly likely that such factors continue as major components of variability in survival following outmigration.

This study showed that selenium concentrations were higher in naturally reared coho salmon than they were in hatchery-reared fish. Further, the results showed that the difference in selenium concentrations in naturally reared and hatchery-reared salmon was statistically significant, regardless of whether one examined adult fish $(p<0.05)$ or smolts $(p<0.0025)$.

Poppe et al. (1985) demonstrated more striking differences in adult Atlantic salmon Salmo salar than we found in coho salmon. The wild Atlantic salmon livers had selenium levels that were 7 times higher than those of hatchery fish, as compared with 1.64 times higher in our study. This may represent a species difference.

Selenium affects the immune response by influencing the activity of glutathione peroxidase (GPX). GPX is an antioxidant that protects cellular membranes and 
organelles from peroxidative damage by $\mathrm{H}_{2} \mathrm{O}_{2}$ and superoxide radicals, which are produced by activated phagocytes during the bacterial phagocytosis process. Because of this interaction, selenium has attracted the attention of investigators investigating potential methods to enhance disease resistance in man and domestic animals (Diplock 1981).

The strong relationships that exist between selenium deficiency and compromised immune responses have been demonstrated by Spallholz et al. (1973), Koller et al. (1979), Sheffy \& Schultz (1979), Desowitz \& Barnwell (1980) and Purnham et al. (1983). These studies indicated that (1) animals deficient in Se and vitamin $E$ have lower antibody titers than non-deficient animals in response to vaccinations, (2) an excess of dietary $\mathrm{Se}$ can enhance the efficacy of a killed vaccine, (3) Se enhances antibody synthesis, and (4) Se deficiency hinders mitogenic stimulation of lymphocytes in both dogs and mice.

Literature on selenium deficiency and disease resistance in fish is not extensive. King (1975) showed that selenium deficiency caused muscular dystrophy and steatitis in juvenile rainbow trout (Oncorhynchus mykiss, formerly Salmo gairdneri). Hilton et al. (1980) studied nutritional requirements and toxicity levels in rainbow trout and found that selenium levels in dry feed of $13 \mu \mathrm{g} \mathrm{g}^{-1}$ and 0.15 to $0.38 \mu \mathrm{g} \mathrm{g}^{-1}$ produced chronic toxicity and maximal GPX activity, respectively. Hilton \& Hodson (1983) demonstrated an effect of increased dietary carbohydrates on selenium metabolism and toxicity. Selenium deficiency in Atlantic salmon (Poston et al. 1976) and rainbow trout (Hilton \& Hodson 1983) caused a reduction in plasma GPX activity. Gatlim \& Wilson (1984) established a dietary requirement of $250 \mu \mathrm{g} \mathrm{Se} \mathrm{kg}^{-1}$ dry diet for fingerling channel catfish.

Bell et al. (1986), in investigating selenium in rainbow trout and Atlantic salmon, found GPX activity in rainbow trout to be significantly reduced in selenium deficiency. They also found hepatic glutathione-stransferase and pyruvate kinase activity to be increased in selenium-deficient Atlantic salmon parr (Bell et al. 1987). In addition, they showed that pyruvate kinase increased and that liver GPX activity decreased in Atlantic salmon with pancreatic disease (Bell et al. 1987). The selenium sufficient diets used in the Bell et al. studies contained approximately $1.0 \mathrm{mg}$ Se $\mathrm{kg}^{-1}$ dry diet. This concentration compares favorably with that of the Oregon Moist Pellet diet used in our study.

Poppe et al. (1986) found a difference in selenium concentrations between healthy, farm-reared fish and farm-reared fish suffering from a hemorrhagic syndrome known as Hitra Disease (2.4 vs $1.8 \mathrm{ug} \mathrm{Se} \mathrm{g}^{-1}$ wet wt). Poppe et al. (1985) supported the hypothesis that hemorrhagic syndrome (HS) is a nutritional or metabolic disorder with their finding of muscular dystrophy in apparently healthy fish from farms with HS. Also, they noted that bacteria are seldom detected or isolated from such fish, although they are easily demonstrated in later stages of this disease. Further, they postulated that the slow-growing, cold-water $\mathrm{Vi}$ brio salmonicida, isolated from salmon with $\mathrm{HS}$, may be a secondary invader in a host already weakened and stressed by nutritional or metabolic disorders in addition to other environmental stresses.

Research suggests that salmonids can tolerate higher selenium concentrations in the form of sodium selenite than the forms now available in commercial diets (Bell \& Cowey 1989). In a recent study conducted in our laboratory, a commercial diet containing $1.1 \mu \mathrm{g}$ Se $\mathrm{g}^{-1}$ was supplemented by the addition of $0.0,0.5,2.5$ or $5.5 \mu \mathrm{g} \mathrm{Se} \mathrm{g}^{-1}$. When fed to Atlantic salmon over a period of $7 \mathrm{mo}$, no signs of toxicity were noted (Felion et al. 1989).

What is the significance of the difference in selenium levels between wild and hatchery-reared fish? A difference of between only 50 and $100 \%$ may well be significant, particularly as the margin between deficiency and toxicity is very narrow. Is it possible that the difference contributes to better health of wild fish? Also, do higher selenium levels in naturally reared salmon smolts enhance resistance to invasive diseases during the dramatic metabolic changes that occur at the time of saltwater adaptation? If so, this may partly account for the better post-release survival rates of naturally reared fish. It is also possible that hatchery practices may induce stress responses that deplete micronutrient stores of $\mathrm{Cu}, \mathrm{Zn}$, and $\mathrm{Se}$ and thus alter the ability of fish to withstand disease. These hypotheses will be tested in studies on hatchery-reared fish in which selenium. levels will be brought up to those found in wild fish. Post-release survival rates and disease resistance will then be examined in supplemented and non-supplemented groups. Information from these studies may well play a role in the enhancement of survival rates in. hatchery-reared fish.

\section{LITERATURE CITED}

Adeloju, S. B., Bond, A. M. (1983). Stripping voltammetric determination of selenium in biological materials by direction calibration. Analyt. Chem. 55: 2076-2082

Bell, J. G., Cowey, C. B., Adron, J. W., Pirie, B. J. S. (1987). Some effects of selenium deficiency on enzyme activities and indices of tissue peroxidation in Atlantic salmon parr (Salmo salar). Aquaculture 65: 43-54

Bell, J. G., Pirie, B. J. S., Adron, J. W. Cowey, C. B. (1986). Some effects of selenium deficiency on glutathione peroxidase (EC1.11.1.9) activity and tissue pathology in rainbow trout Salmo gairdneri. Br. J. Nutr. 55: 305-311 
Bell, J. G., Cowey, C. B. (1989). Digestibility and bioavailability of dietary selenium from fishmeal, selenite, selenomethionine and selenocystine in Atlantic salmon (Salmo salar). Aquaculture 81: 61-68

Desowitz, R. S., Barnwell, C. W (1980). Effects of selenium and dimethyl dioctacleyl ammonium bromide on the vaccine induced immunity of Swiss-Webster mice against malaria (Plasmodium berghei). Infection Immunity 27 : $87-89$

Diplock, A. J. (1981). The role of vitamin $E$ and selenium in prevention of oxygen induced tissue damage. In: Spallholz, J. E., Martin, J. L., Ganther, H. E. (eds). Selenium in biology and medicine. A.V.I. Pub. Co. Inc. Westport, CT, p. 303-316

Felton, S. P., Smith, L. S., Ji, W., Halver, J. E. (1989). Implications of selenium involvement during chemical and physical stresses in salmonids. Proc. Soc. exp. Biol. Med. $190(3): 303$

Gatlin, D. M. III, Wilson, R. P. (1984). Dietary selenium requirements of fingerling channel catfish. J. Nutr. 114: $627-633$

Hilton, J. W., Hodson, P. V. (1983). Effect of increased dietary carbohydrate on selenium metabolism and toxicity in rainbow trout Salmo gairdneri. J. Nutr. 113: 1241-1248

Hilton, J. W., Hodson, P. V., Slinger, S. J. (1980). The requirement and toxicity of selenium in rainbow trout Salmo gairdneri. J. Nutr. 110: 2527-2535

Hodson, P. V., Hilton, J. W. (1983). The nutritional requirements and toxicity to fish of dietary and waterborne selenium. In: Hallberg, R. (ed.) Environmental biogeochemistry. Ecology Bulletin, Stockholm, p. 335-340

Responsible Subject Editor: Dr T. Evelyn, Nanaimo, B.C., Canada
King, J. M. (1975). Nutritional myopathy in fish. In: Ribelin, W. E., Migaki, G. (eds.) The pathology of fishes. Univ. Wisconsin Press, Madison, WI, p. 787-792

Koller, L. D., Kervliet, N. I., Exon, J. H. (1979). Synergism of methylmercury and selenium producing enhanced antibody formation in mice. Archs. envirl Hith 34: 248-252

Poppe, T., Hastein, T., Froslie, A., Horheim, G., Heum, M. (1985). Vitamin E, selenium, copper and zinc in Atlantic salmon Salmo salar L.: comparative studies of wild and farmed fish. Bull. Eur. Ass. Fish Pathol. 5(2): 28-29

Poppe, T., Hastein, T., Froslie, A., Koppang, N, Horheim, G. (1986). Nutritional aspects of haemorrhagic syndrome ('Hitra Disease') in farmed Atlantic salmon Salmo salar. Dis. aquat. Org. 1: 155-162

Poston, H. A., Combs, G. F. Jr, Leibovitz, L. (1976). Vitamin E and selenium interrelations in the diet of Atlantic salmon Salmo salar; gross, histological and biochemical deficiency signs. J. Nutr. 106: 892-904

Purnham, M. F., Winkelmann, J., Leycks, S. (1983). Macrophage, lymphocyte, and chronic inflammatory responses in selenium deficient rodents; association with decreased glutathione peroxidase activity. Int. J. Immunopharmac. 5: $455-461$

Ringdal, O., Julshamn, K. (1985). Selenium - an important nutrient for salmonids. Fisk. Gang. 9(18): 317-318

Sheffy, B. E., Schultz, R. D. (1979). Influence of vitamin E and selenium on immune response mechanisms. Fedn. Proc. Fedn. Am. Socs. exp. Biol. 38: 2139-2143

Spallholz, J. E., Martin, J. L., Gerlach, M. C., Heinzerling, R. H. (1973). Immunological responses of mice fed diets supplemented with selenite selenium. Proc. Soc. exp. Biol. Med. 143: 685-698

Manuscript first received: May 18, 1990

Revised version accepted: July 27, 1990 